\title{
Improving decolorization of dyes by laccase from Bacillus licheniformis by random and site-directed mutagenesis
}

\author{
Tongliang Bu ${ }^{\text {Corresp., Equal first author, } 1}{ }^{1}$, Rui Yang ${ }^{\text {Equal frst author, }{ }^{1} \text {, YanJun Zhang }}{ }^{1}$, Yuntao Cai ${ }^{1}$, Zizhong Tang $^{1}$, Chenglei Li $^{1}$, Qi \\ Wu ${ }^{1}$, Hui Chen ${ }^{1}$ \\ ${ }^{1}$ College of Life Sciences, Sichuan Agricultural University, Ya'an, China \\ Corresponding Author: Tongliang Bu \\ Email address: 13941@sicau.edu.cn
}

Background. Dye wastewater increases cancer risk in humans. For the treatment of dyestuffs, biodegradation has the advantages of economy, high efficiency, and environmental protection compared with traditional physical and chemical methods. Laccase is the best candidate for dye degradation because of its multiple substrates and pollution-free products. Methods. Here, we modified the laccase gene of Bacillus licheniformis by error-prone PCR and site-directed mutagenesis and expressed in E. coli. The protein was purified by His-tagged protein purification kit. We tested the enzymatic properties of wild type and mutant laccase by single factor test, and further evaluated the decolorization ability of laccase to acid violet, alphazurine $A$, and methyl orange by spectrophotometry. Results. Mutant laccase Lac ${ }^{\mathrm{ep} 69}$ and D500G were superior to wild type laccase in enzyme activity, stability, and decolorization ability. Moreover, the laccase D500G obtained by site-directed mutagenesis had higher enzyme activity in both, and the specific activity of the purified enzyme was as high as $426.13 \mathrm{U} / \mathrm{mg}$. Also, D500G has a higher optimum temperature of $70^{\circ} \mathrm{C}$ and temperature stability, while it has a more neutral pH 4.5 and pH stability. D500G had the maximum enzyme activity at a copper ion concentration of $12 \mathrm{mM}$. The results of decolorization experiments showed that D500G had a strong overall decolorization ability, with a lower decolorization rate of $18 \%$ for methyl orange and a higher decolorization rate of $78 \%$ for acid violet. Conclusion. Compared with the wild type laccase, the enzyme activity of D500G was significantly increased. At the same time, it has obvious advantages in the decolorization effect of different dyes. Also, the advantages of temperature and $\mathrm{pH}$ stability increase its tolerance to the environment of dye wastewater. 
$1 \quad$ Improving decolorization of dyes by laccase from Bacillus

$2 \quad$ licheniformis by random and site-directed mutagenesis

3 Tongliang $\mathrm{Bu}^{12^{*}}$, Rui Yang ${ }^{12}$, Yanjun Zhang ${ }^{1}$, Yuntao Cai ${ }^{1}$, Zizhong Tang ${ }^{1}$, Chenglei Li ${ }^{1}$ Qi Wu ${ }^{1}$,

4 Hui Chen ${ }^{1}$

5 1. College of Life Sciences, Sichuan Agricultural University, Ya'an 625014, China

6 *Corresponding author:

7 Tongliang Bu, Tel: +86 0835 2886126; Fax: +86 0835 2886136; E-mail: 13941@sicau.edu.cn

8 2. These authors contributed equally to this work and should be considered co-first authors.

\section{ABSTRACT:}

10 Background. Dye wastewater increases cancer risk in humans. For the treatment of dyestuffs,

11 biodegradation has the advantages of economy, high efficiency, and environmental protection

12 compared with traditional physical and chemical methods. Laccase is the best candidate for dye

13 degradation because of its multiple substrates and pollution-free products.

14 Methods. Here, we modified the laccase gene of Bacillus licheniformis by error-prone PCR and

15 site-directed mutagenesis and expressed in E. coli. The protein was purified by His-tagged protein

16 purification kit. We tested the enzymatic properties of wild type and mutant laccase by single

17 factor test, and further evaluated the decolorization ability of laccase to acid violet, alphazurine A,

18 and methyl orange by spectrophotometry.

19 Results. Mutant laccase Lac ${ }^{\mathrm{ep} 69}$ and D500G were superior to wild type laccase in enzyme activity,

20 stability, and decolorization ability. Moreover, the laccase D500G obtained by site-directed 
21 mutagenesis had higher enzyme activity in both, and the specific activity of the purified enzyme

22 was as high as $426.13 \mathrm{U} / \mathrm{mg}$. Also, D500G has a higher optimum temperature of $70^{\circ} \mathrm{C}$ and temperature stability, while it has a more neutral $\mathrm{pH} 4.5$ and $\mathrm{pH}$ stability. D500G had the maximum enzyme activity at a copper ion concentration of $12 \mathrm{mM}$. The results of decolorization experiments showed that D500G had a strong overall decolorization ability, with a lower decolorization rate of $18 \%$ for methyl orange and a higher decolorization rate of $78 \%$ for acid violet.

Conclusion. Compared with the wild type laccase, the enzyme activity of D500G was significantly increased. At the same time, it has obvious advantages in the decolorization effect of different dyes. Also, the advantages of temperature and $\mathrm{pH}$ stability increase its tolerance to the environment of dye wastewater.

31 Keywords: dye degradation, bacteria laccase, error-prone PCR, site-directed

\section{INTRODUCTION} oxidase, belong to the superfamily of blue poly copper oxidases (MCOs) (Morozova et al., 2007; Hakulinen \& Rouvinen, 2015). Laccase was first discovered in the permeate of Rhus vernicifera (Legrand \& Martin, 1958). Thereafter, they were also found in plants, fungi, bacteria, and insects (Chakroun et al., 2010; Forootanfar et al., 2011; Halaburgi et al., 2011). There are many studies on fungal laccase and bacterial laccase. White rot fungi of the basidiomycete family are mostly studied in laccase-producing fungi. At present, it has been found that bacterial laccase mainly comes from Bacillus sp. (Mollania et al., 2011; Chen et al., 2017), Streptomyces (Freeman et al., 
41 1993), and Pseudomonas (Francis \& Tebo, 2001). Laccases can catalyze phenols, polyphenols

42 (Koschorreck et al., 2008; Zeng et al., 2011; Revanth, Niranjan \& Sarma, 2020), polycyclic

43 aromatic hydrocarbons, certain inorganic substances, and more. As a result, they are widely used

44 for the decolorization of synthetic dyes (Pereira et al., 2009; Mendes et al., 2011), synthesis of

45 organic substances, food processing, biosensor (Zhang et al., 2019), and other fields. The

46 molecular structure of laccase contains four copper ions. There are three types based on magnetic

47 and spectral properties: Type 1 (T1), Type 2 (T2), and type 3 (T3) copper ions. $\mathrm{T} 1 \mathrm{Cu}^{2+}$, located

48 at the substrate-binding site, is responsible for transferring substrate electrons (Martins et al.,

49 2015). $\mathrm{T} 2 \mathrm{Cu}^{2+}$ and $\mathrm{T} 3 \mathrm{Cu}^{2+}$ are located at the oxygen molecule binding site, where oxygen

50 molecules combine with electrons to generate water (Sakurai \& Kataoka, 2007, 2010).

51 Dye wastewater has become one of the main hazardous industrial sewage due to a large

52 number of dyes and intermediates. According to chemical properties, dyes are divided into reactive

53 dyes, acid dyes, basic dyes, disperse dyes, vat dyes, sulfur dyes, mordants, direct dyes, naphthol

54 dyes, solvent dyes, and organic pigments (Bhatia et al., 2017). Synthetic dyes with strong

55 carcinogenic polycyclic aromatic hydrocarbons as raw materials have become more commonly

56 used dyes in the printing and dyeing industry because of their stable physical and chemical

57 properties and low cost. Wastewater from the printing and dyeing industry is discharged into

58 freshwater without treatment, which seriously affects the growth of aquatic organisms and

59 microorganisms (Mishra \& Maiti, 2018), and destroys the self-purification of water bodies

60 (Tkaczyk et al., 2020; Gowri et al., 2014). At the same time, azo and anthraquinone dyes will

61 produce a variety of carcinogenic aromatic amines during specific decomposition, which can cause 
62 cancer, mutagenesis, and reproductive toxicity (Ali et al., 2019). The objects of this study are both

63 azo (methyl orange, alphazurine A) and anthraquinone (acid violet) dyes that are acid.

64 In terms of dye degradation, white rot fungal laccase has many problems, such as a long

65 culture period and high cost. Therefore, researchers turned their attention to bacterial laccase.

66 (Michniewicz et al., 2008; Hadibarata et al., 2012; Tian et al., 2014; Zheng et al., 2017; Legerská,

67 Chmelová \& Ondrejovič, 2018). In 1993, Givaudan first detected laccase activity in Awspirillum

68 lipoferum (Givaudan et al., 1993). Numerous studies have shown that certain bacterial laccases,

69 such as CotA laccases from Bacillus capsid protein, are more tolerant than fungal laccase in neutral

70 or alkaline environments. (Zhang et al. 2012; Lu et al., 2012; Guan et al., 2014; Martins et al.,

71 2015; Wang et al., 2016). This bacterial laccase is more suitable for the environment of dye

72 wastewater and exhibits higher enzyme activity. However, the enzyme activity of a crude enzyme

73 solution of wild bacterial laccase is often lower. Direct modification of proteins is an effective way

74 to improve enzyme activity and stability (Chen et al., 2017). This technology mainly includes two

75 strategies: rational design and directed evolution. Rational designs are usually based on computer-

76 aided structural modeling of enzyme proteins, using site-directed mutation techniques, knockout,

77 and insertions of protein sequences to alter the properties and functions of the target protein.

78 Finally, target protein properties were analyzed by measuring enzyme activity. Directed evolution

79 aims to construct a set of random gene transformations in vitro by mimicking natural evolution,

80 and then select target proteins through library construction and high-throughput screening. It can

81 be achieved by error-prone PCR and DNA recombination techniques (Bornscheuer \& Pohl, 2001;

82 Berman, 2008). 
83 Here, we used a laboratory-constructed plasmid containing laccase constructed by Bacillus

84 licheniformis as a template, modified target genes by error-prone PCR and site-directed mutation,

85 screened mutants with higher enzyme activity, and further evaluated the decolorization ability of

86 wild-type and mutant laccase to dyes.

\section{MATERIALS AND METHODS}

$88 \quad 2.1$ Materials

89 2.1.1 Strains and Plasmid

90 The sources of bacterial strains, vectors, and engineered bacteria used in this article were

91 shown in Table 1. All strains besides cold-induced expression were grown in Luria-Bertani (LB)

92 medium at $37^{\circ} \mathrm{C}$.

93 2.1.2 Chemicals and Apparatus

94 Diammonium 2,2'-azino-bis (3-ethylbenzothiazoline-6-sulfonic sulfonate, ABTS), acid violet,

95 alphazurine A, and methyl orange were purchased from Sigma-Aldrich (St. Louis, MO, USA).

96 Restriction enzymes EcoR I, Kpn I, Prime STAR Max, DNA Maker, and Protein Maker all

97 purchased from TaKaRa (Dalian China). The bacterial genomic DNA extraction kit, instant error-

98 prone PCR kit, agarose gel DNA recovery kit, plasmid extraction kit, and fast site-directed

99 mutagenesis kit all purchased from TianGen (Beijing, China). Ampicillin, kanamycin, and IPTG

100 were purchased from Solarbio (Beijing, China). His-tagged protein purification kit was purchased

101 from Kangweishiji (Beijing, China). All other chemicals were standard reagent grade. 
102 PCR instrument (T100 ${ }^{\mathrm{TM}}$ Thermal Cycler, Bio-Rad) Molecular Devices Spectra Max M2

103 microplate reader, Ultrasonic processor type ultrasonic crusher, E-201-C type pH composite

104 electrode, ZWY-211C constant temperature, Constant temperature incubator, Nucleic acid

105 electrophoresis equipment, Protein electrophoresis equipment, and other equipment. digital $\mathrm{pH}$

106 meter (PHS-25, Shanghai Instrument and Electric Scientific Instrument Co., Ltd.), E-201-C type

$107 \mathrm{pH}$ composite electrode.

$108 \quad 2.2$ Enzyme activity assay

109 Laccase oxidation reaction was carried out at $50^{\circ} \mathrm{C}$ in vitro, using ABTS as a substrate. In a

110 solution containing $50 \mathrm{mM}$ tartaric acid buffer (pH 3.0), $1 \mathrm{mM} \mathrm{ABTS}$ and $1 \mathrm{mM} \mathrm{CuCl} 2300 \mu \mathrm{L}$ of

111 enzyme solution was added to $3 \mathrm{~mL}$ of reaction system. After 5 minutes of reaction, the absorbance

112 at $420 \mathrm{~nm}$ was measured. Under the above conditions, the amount of enzyme required to oxidize

$1131 \mu \mathrm{mol}$ of ABTS per minute is defined as one unit of enzyme activity $(\mathrm{U})$. The assay was performed

114 in quadruplicate. According to the study of Lu et al., some modifications were made to the enzyme

115 activity determination method (Lu et al., 2012).

116 The formula for calculating enzyme activity is shown in Eq. (1).

$117 \mathrm{U}(\mathrm{U} / \mathrm{mL})=\frac{\Delta \mathrm{A}}{\varepsilon b t} \times \frac{V_{1}}{V_{2}} \times n \times 10^{6}$

118 Where $\Delta \mathrm{A}$ represents absorbance change value in time $(\mathrm{t}), \mathrm{b}$ is the thickness of cuvette $(\mathrm{cm})$, and

$119 \mathrm{t}$ is the reaction time ( $\mathrm{min}) . \mathrm{V}_{1}$ and $\mathrm{V}_{2}$ represent the volume of the reaction system (L) and a crude

120 enzyme solution (L), respectively. $\mathrm{n}$ is a dilution ratio. ABTS: $\varepsilon_{420}=36000 \mu^{-1} \cdot \mathrm{cm}^{-1}$. 
121

122

123

124

125

126

2.4 Site-directed mutagenesis

\subsection{Error-Prone PCR} enzyme activity were screened.

The laccase gene of $B$. licheniformis was randomly mutated by using the constructed recombinant plasmid pET-Lac containing the Lac gene as the template and adding the specific primers containing the enzyme cutting site (Table 2). (Note: The error-prone PCR kit is only suitable for reactions with a gene length of less than $1,000 \mathrm{bp}$, but the Lac gene is 1,542 bp, so segmented PCR is performed). The mutant laccase gene was ligated with the linearized vector pET-30b $(+)$ to form the recombinant plasmid pET-Lac ${ }^{e p}$, then transformed into E. coli BL21 competent cells, and then the positive transformants were screened with LB medium containing ampicillin. Using ABTS as a substrate, a 96-well plate method was used to screen mutants with laccase activity. Positive clones were sequentially added to 96-well plates for overnight culture, in which $200 \mu \mathrm{L}$ of resistance medium was added to the wells beforehand. The $10 \mu \mathrm{L}$ culture was added to a new 96-well plate in turn and incubated for $4 \mathrm{~h}$ using IPTG induction. After the culture, the bacteria were precipitated at $-80^{\circ} \mathrm{C}$ and repeatedly frozen and thawed three times. The bacteria were resuspended with Tri-HCl and lysed with lysozyme, and the lysate was centrifuged to obtain the supernatant. Enzyme activity of the supernatant was determined and mutants with higher

Forward and reverse mutation primers Lac-D-F and Lac-D-R were designed using the fast sitedirected mutagenesis kit. Using plasmid pET-Lac containing Lac as a template amplified mutant Lac. PCR products were digested using $1 \mu \mathrm{L} D p n$ I enzyme $(20 \mathrm{U} / \mu \mathrm{L})$ at $37^{\circ} \mathrm{C}$ for $1 \mathrm{~h}$. The $D p n \mathrm{I}$ 
141 enzyme can digest methylated templates. After treatment with $D p n$ I enzyme, it was then

142 transformed into FDM competent cells. All mutants were screened and further confirmed by DNA

143 sequencing. Plasmids containing the desired mutations were then transformed into E. coli BL21

144 (DE3) for protein expression.

145 2.5 Expression and Purification of laccases

146 E. coli BL21 (DE3) containing WT laccases gene (Lac) and mutant laccase genes (Lacep69 and

147 D500G) were cultured overnight in $10 \mathrm{~mL} \mathrm{LB}$ medium containing ampicillin $(100 \mathrm{mg} / \mathrm{mL})$ at $37^{\circ} \mathrm{C}$

148 with shaking (180 rpm). Afterward, the overnight pre-culture was inoculated into a fresh $50 \mathrm{~mL}$

149 culture medium ( $1 \%$ inoculation) containing ampicillin $(100 \mathrm{mg} / \mathrm{mL})$ and incubated at $37^{\circ} \mathrm{C}$ with

150 shaking $(180 \mathrm{rpm})$ until an optical density at $600 \mathrm{~nm}\left(\mathrm{OD}_{600}\right)$ of 0.6 was reached. Then, isopropyl-

$151 \beta$-D-1-thiogalactopyranoside (IPTG) was added to the culture medium to a final concentration of

$1520.1 \mathrm{mM}$, and the culture was induced at $16^{\circ} \mathrm{C}, 100 \mathrm{rpm}$. Samples were taken every two hours and

$15312 \%$ SDS-PAGE was used to detect the expression of target proteins (Laemmli, 1970). Meanwhile,

154 E. coli BL21 cells containing empty vector pET-30b $(+)$ were used as control. Centrifuge (10 min,

$\left.1558,000 \times \mathrm{g}, 4^{\circ} \mathrm{C}\right)$ to collect induced bacterial cells. Cells were crushed on ice and centrifuged (20

$156 \min , 8,000 \times \mathrm{g}, 4^{\circ} \mathrm{C}$ ) to remove cell debris. Then, the supernatant was treated at $70^{\circ} \mathrm{C}$ for $15 \mathrm{~min}$,

157 and the denatured protein was removed by centrifugation $\left(10 \mathrm{~min}, 10,000 \times \mathrm{g}, 4^{\circ} \mathrm{C}\right)($ Koschorreck,

158 Schmid \& Urlacher, 2009; Nasoohi et al., 2013).

159 Based on the histidine tag carried on the vector pET-30b $(+)$, we purified the recombinant

160 laccase using the His-tagged protein purification kit. Then, according to the SDS-PAGE results, 
161 the pure enzyme solution was desalted by Amicon ultrafiltration (membrane retention value: 10

$162 \mathrm{kDa}$; Millipore, Billerica, Ma, USA). According to Bradford's method, bovine serum albumin was

163 used to make the protein standard curve, and the protein content of purified laccase was determined

164 (Bradford, 1976).

1652.6 Characterization of laccases

166 2.6.1 Optimum temperature and thermal stability

167 Optimum temperature and temperature stability of purified laccase activity were assessed by 168 relative enzyme activity measured at different temperatures. The enzyme activity of laccase at 169 different temperatures was measured after incubation at $50,55,60,65,70,75,80,85,90,95$, and $170100^{\circ} \mathrm{C}$ for 1 hour under standard conditions, and the enzyme activity measured at $4^{\circ} \mathrm{C}$ was defined 171 as $100 \%$.

172 2.6.2 Optimum $\mathrm{pH}$ and $\mathrm{pH}$ stability

173 Optimum $\mathrm{pH}$ and $\mathrm{pH}$ stability of purified laccase activity were assessed by relative enzyme 174 activity measured at $\mathrm{pH} 2.0,2.5,3.0,3.5,4.0,4.5,5.0,5.5,6.0,6.5$ under standard conditions, 175 respectively. The $\mathrm{pH}$ of the enzyme reaction system was adjusted by $0.05 \mathrm{M}$ citric acid- $\mathrm{Na}_{2} \mathrm{HPO}_{4}$

176 buffer to $2.0,2.5,3.0,3.5,4.0,4.5,5.0,5.5,6.0,6.5$, and incubated at $4^{\circ} \mathrm{C}$ overnight to measure

177 the enzyme activity at different $\mathrm{pH}$. The enzyme activity measured under $\mathrm{pH} 4$ was defined as $178100 \%$, and the relative enzyme activity was calculated.

179 2.6.3 Copper ion concentration 
180 To detect the effect of copper ion concentration on laccase activity, $\mathrm{CuCl}_{2}$ solution with a final

181 concentration of $0,0.2,0.4,0.6,0.8,1.0,1.2,1.4,1.6,1.8,2.0 \mathrm{mM}$ was added to the reaction

182 system, and laccase activity was determined under the optimum reaction conditions. The relative

183 enzyme activity was calculated by taking the laccase enzyme activity measured under the same

184 reaction system without adding $\mathrm{CuCl}_{2}$ solution was determined to be $100 \%$. The data were

185 processed and analyzed using Origin 8.0 software. The decolorization rate calculation formula is

186 shown in Eq. (2).

$187 \mathrm{D}=\frac{\mathrm{A}_{0}-\mathrm{A}_{1}}{\mathrm{~A}_{0}} \times 100 \%$

188 Where D represents the decolorization rate $(\%), \mathrm{A}_{0}$ is the initial absorbance of the dye solution at

189 the maximum absorption wavelength, $\mathrm{A}_{1}$ results from the initial absorbance of the dye solution at

190 the maximum absorption wavelength after the reaction.

$191 \quad 2.7$ Dye decolorization

192 The decolorization ability of Lac, Lac ${ }^{\mathrm{ep} 69}$, and D500G was tested with three dyes of acid violet

$193\left(\lambda_{\max }=600 \mathrm{~nm}\right)$, alphazurine A $\left(\lambda_{\max }=637 \mathrm{~nm}\right)$, and methyl orange $\left(\lambda_{\max }=470 \mathrm{~nm}\right)$. Add $100 \mathrm{mg} / \mathrm{mL}$

194 purified enzyme protein, dye $(40 \mathrm{mg} / \mathrm{L}$ acid violet, $20 \mathrm{mg} / \mathrm{L}$ alphazurine $\mathrm{A}, 20 \mathrm{mg} / \mathrm{L}$ methyl

195 orange) and $1 \mathrm{mM} \mathrm{CuCl} 2$ to tartaric acid buffer $(0.1 \mathrm{M}, \mathrm{pH} 4.0)$ for decolorization reaction.

196 Samples were taken and centrifuged regularly $(12,000 \mathrm{rpm}, 2 \mathrm{~min})$, and the decolorization effect

197 was determined by spectrophotometry. All reactions are performed in quadruplicate. 
199 Using DANAMAN, ProtParam (http://web.expasy.org/protparam/), SOPMA

200 (http://www.expasy.ch/swissmod/SWISS-MODEL.heml), $\quad$ and Swiss-Model

201 (http://www.expasy.ch/swissmod/SWISS-MODEL.heml) tools for gene sequence comparison,

202 basic property analysis, secondary structure prediction, and tertiary structure prediction of laccases

203 from wild-type and mutant strains, respectively.

2042.9 Statistical analysis

205 Quadruplicate in experiments was conducted on each sample to ensure good repeatability.

206 Statistical Program of Social Science (SPSS 17.0, Chicago, IL, USA) software was used for one-

207 way analysis of variance (ANOVA) by using Duncan's test of the data to complete the significant

208 difference test, at a significant level of $\mathrm{P}<0.05$.

\section{RESULTS}

2103.1 Expression and purification of wild-type and mutant laccases

211 Nucleotide sequencing of the plasmid extracted from the positive transformant confirmed that

212 Lac's ORF contains 1,542 bp that theoretically encode 513 amino acids with a molecular weight

213 of about $60 \mathrm{kDa}$. (S1) The protein sequence has a 99\% identity to the Lac gene of B. licheniformis

214 (MK427697.1).

215 The results of SDS-PAGE showed that the enzyme expression reached the highest level, after

21610 hours of IPTG induction. Because the expression level increases from 2 to 10 hours, 10 to 12

217 hours tends to remain unchanged. The results were shown in Fig. 1. After 10 hours of induction, 
218 the cells were sonicated and purified. SDS-PAGE electrophoresis results of the purified product,

219 intracellular supernatant, and cell debris are shown in Fig. 2. We found that under low temperature

220 and low concentration inducer conditions, the recombinant Lac was mainly expressed in a soluble

221 state but has a low content in the precipitate. And after purification, a single band can be obtained

222 (Lane 1). Using ABTS as the substrate, the specific activity of the purified Lac was $121.75 \mathrm{U} / \mathrm{mg}$.

223 Here, we used a 96-well plate method to screen a mutant strain Lac ${ }^{\text {ep69 }}$ with higher enzyme

224 activity than Lac, from the mutated Lac gene library generated by error-prone PCR. The mutant

225 strain Lac ${ }^{\mathrm{ep} 69}$ 's specific activity is $51.24 \mathrm{U} / \mathrm{mg}$, which was 1.35 times higher than that of the wild

226 strain $37.84 \mathrm{U} / \mathrm{mg}$. After the alignment of multiple laccase gene sequences, we found a conserved

227 aspartic acid at position 500 of the laccase, replacing aspartic acid with glycine to carry out the

228 targeted modification of laccase (The data isn't displayed). The specific activity of Lac ${ }^{\text {ep69 }}$ was

$229170.45 \mathrm{U} / \mathrm{mg}$, and D500G was $426.13 \mathrm{U} / \mathrm{mg}$.

2303.2 Characterization of the purified wild-type and mutated laccases

231 3.2.1 Optimal $\mathrm{pH}$ and $\mathrm{pH}$ stability

232 The optimized $\mathrm{pH}$ and $\mathrm{pH}$ stability results of Lac, Lac ${ }^{\mathrm{ep} 69}$, D500G after purification are shown

233 in Fig. 3A, 3B. Lac ${ }^{\mathrm{ep} 69}$ and Lac have the same optimal $\mathrm{pH}$ of 4.0, while D500G is more neutral

234 than Lac, with a $\mathrm{pH}$ increase of 0.5 . Fig. 3B shows that at a $\mathrm{pH}$ of $4.0-5.5$, the relative enzyme

235 activity of Lac ${ }^{\mathrm{ep} 69}$ after 1 hour of incubation is stable above $75 \%$, while the relative enzyme activity

236 of D500G after 1 hour of incubation at 4.5-6.5 is stable above 80\%. In contrast, D500G has higher

237 enzyme activity and stability in a neutral environment. 
238 3.2.2 Optimum temperature and temperature stability

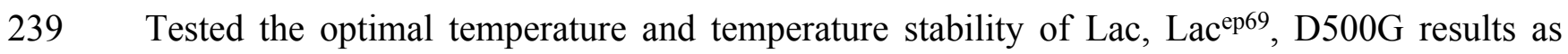

240 shown in Fig. 3C, 3D. The optimum temperature for both Lac ${ }^{\mathrm{ep} 69}$ and D500G was higher than Lac,

241 which was 80 and $70^{\circ} \mathrm{C}$ respectively. Their temperature stability is high. After incubating at 50-

$24280^{\circ} \mathrm{C}$ for 1 hour, Lac ${ }^{\mathrm{ep} 69}$ enzyme activity remained above $80 \%$, while D500G enzyme activity

243 remained above $85 \%$. It indicated that mutants were more tolerant of temperature than the wild

244 type, had higher enzyme activity in higher temperature environments, and were more suitable for

245 enzyme industrialization. Besides, when the temperature increased to $85^{\circ} \mathrm{C}$ the enzyme activity of

246 Lac, Lac ${ }^{\mathrm{ep} 69}$, and D500G showed a rapid decline trend, indicating that excessive temperature

247 denatured the enzyme and inactivated it.

248 3.2.3 Copper ion concentration

249 Tested the effect of different concentrations of copper ions on enzyme activity. As shown in

250 Fig. 4, when the concentration of copper ions in the reaction system was $12 \mathrm{mM}$, the activity of

251 wild-type laccase reached its peak. However, the mutant strains Lac ${ }^{\mathrm{ep} 69}$ and D500G only need 10

$252 \mathrm{mM}$ copper ion concentration to achieve maximum enzyme activity. This indicated that the mutant

253 was more sensitive to copper ions than the wild type Lac.

$254 \quad 3.2 .4 \mathrm{Km}$ value determination

$255 K \mathrm{~m}$ represents the magnitude of the affinity of the enzyme to the substrate. The larger the $K \mathrm{~m}$,

256 the smaller the affinity of the enzyme and the substrate, the lower the enzyme activity. We used 
257 Origin8.0 software to predict the $\mathrm{km}$ of $\mathrm{Lac}, \mathrm{Lac}^{\mathrm{ep} 69}$, and $\mathrm{D} 500 \mathrm{G}$ after purification. The $\mathrm{Km}$ value

258 of engineered bacteria Lac, mutant strains $\mathrm{Lac}^{\mathrm{ep} 69}$ and D500G was $21.69 \mathrm{mM}, 19.54 \mathrm{mM}$, and

$25910.50 \mathrm{mM}$ respectively, the trends were consistent with the previous experimental of the enzyme

260 protein activity determination, which showed that the increase in affinity leads to the increase in

261 enzyme activity.

2623.3 Dye decolorization assays by laccase

263 Fig. 5A, 5B, and 5C show the decolorization of dyes by within 6 h. First, the rapid reaction

264 phases of Lac, Lac ${ }^{\mathrm{ep} 69}$, and D500G were all 0-1 $\mathrm{h}$. Secondly, the degradation rates of the two

265 mutant enzymes were significantly better than those of the wild type. And D500G has the best

266 decolorization ability. The decolorization rate of Lac to three dyes: methyl orange $15 \%$,

267 alphazurine A 30\%, and acid violet 40\%. The decolorization rate of D500G for three dyes: methyl

268 orange $18 \%$, alphazurine A $70 \%$, and acid violet $78 \%$.

269 As shown in Fig. 5A-C, the enzymatic reaction within 0-1 hour belongs to the rapid reaction

270 period, and the enzyme activity is relatively less affected at this time. Therefore, we compared the

271 decolorization of the three dyes by the wild type and the mutant within 1 hour. The result is shown

272 in Fig. 5D. There are differences in the decolorization rates of different dyes by laccase. Lac,

$273 \mathrm{Lac}^{\mathrm{ep} 69}$, and D500G all have lower degradation rates for methyl orange, but higher degradation

274 rates for alphazurine A and acid violet. For the three dyes, the degradation efficiency of the mutant

275 is always better than that of the wild type. Especially D500G shows a significantly enhanced

276 degradation rate for all three dyes. From the perspective of enzyme activity, the higher enzyme 
277 activity of D500G provides the possibility for dye degradation.

2783.4 Analysis of laccase protein structure

279 The results of the primary structure show that compared with the original Lac, the mutant strain

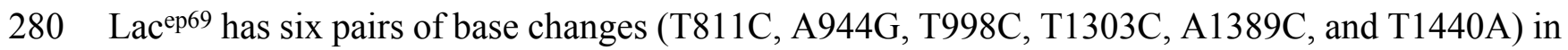

281 the sequence. Correspondingly, the six pairs of amino acids (Cys271Arg, Lys315Arg, Ile333Thr,

282 Phe435Leu, Lys463Asn, Phe480Leu) in Lac ${ }^{\text {ep69 }}$ have also changed.

283 The results of Prote-Param analysis of Lac, Lac ${ }^{\mathrm{ep} 69}$, and D500G are shown in Table 3. First,

284 D500G and Lac ${ }^{\mathrm{ep} 69}$ are stable proteins. According to the stability coefficient data, Lac (40.03)>

$285 \operatorname{Lac}^{\mathrm{ep} 69}$ (39.57)> D500G (39.40). It is noteworthy that D500G has the highest stability. The change

286 of the protein's primary structure will affect its spatial structure, which will affect the

287 intermolecular forces and steric hindrance to varying degrees, thereby changing the stability of the

288 protein. Also, the increase in stability provides theoretical support for the increase in the enzyme

289 activity of D500G. Secondly, wild-type and mutant laccase proteins have similar molecular

290 weights and are both hydrophilic proteins, although the hydrophilicity of Lac ${ }^{\text {ep69 }}$ and D500G is

291 slightly decreased. Amino acid changes, before and after mutation, led to hydrophilic amino acids

292 were replaced by hydrophobic amino acids, hydrophobic R groups to a certain extent weakened

293 the hydrophilicity of enzyme proteins. The difference marks are highlighted in circles in Fig. 6.

294 SOPMA results show that Lac, Lac ${ }^{\mathrm{ep} 69}$, and D500G have similar secondary structures, and they

295 are mainly composed of random coils. The results are shown in Fig. 7. Compared with the wild

296 type, the proportion of $\alpha$-helix in the mutant is increased and the random coil is decreased. Lac has 
$29761.4 \%$ random coils, 8.19\% $\alpha$-helix, 5.26\% $\beta$-turns, and $25.15 \%$ extended chains. Lac ${ }^{\mathrm{ep} 69}$ has

$29860.62 \%$ random curl, $9.36 \% \alpha$-helix, $4.29 \% \beta$-turn, and $25.73 \%$ extended chain. D500G has

$29959.45 \%$ random curl, $8.58 \% \alpha$-helix, $5.85 \% \beta$-turn, and $26.12 \%$ extended chain. Due to the change

300 of amino acids, the proportion of $\alpha$-helix increases, the random curl decreases, and other structural

301 changes are small.

302 Lac, Lac ${ }^{\mathrm{ep} 69}$, and D500G tertiary structure prediction, Swiss-Model analysis results are shown

303 in Fig. 8. The alpha-helical of the mutant laccase $\mathrm{Lac}^{\mathrm{ep} 69}$ is reduced by one, except that the amino

304 acid at position 463 appears on the random curl, and the others are in the $\beta$-turn. The tertiary

305 structure of Lac ${ }^{\mathrm{ep} 69}$ is similar to Lac. However, the $\alpha$-helix and $\beta$-turn angles of D500G are reduced,

306 and the structure shows a loose transition state, in which the amino acid at position 500 appears

307 on the $\beta$-turn angle. The mutated base is located near the active center of the enzyme, which may

308 increase the activity of the enzyme. Lac, Lac ${ }^{\mathrm{ep} 69}$, and D500G mutation sites are shown in Fig. 9.

309 Overall, the number of Lac ${ }^{\mathrm{ep} 69}$ hydrogen bonds didn't change. Changes in amino acids affect the

310 distribution of the atomic electron cloud around the atom. Changes in the electron cloud and

311 hydrogen bonds may be one of the reasons affecting the enzyme activity of laccase.

\section{DISCUSSION}

313 The crude laccase enzyme activity of the original B. licheniformis in this study was only 11.99

$314 \mathrm{U} / \mathrm{mg}$, which is because the endogenous expression level of most bacterial laccases is relatively

315 low (Chen et al., 2015). While heterologous expression of laccase is one of the effective ways to

316 solve this poser. The low expression level of wild-type laccase is the key to the low activity of the 
317 crude enzyme solution of $B$. licheniformis. Also, laccase belongs to intracellular localization, $E$.

318 coli expression system is a better choice (Wu et al., 2010). So, we obtained a 1.37-fold increase in

319 the expression of recombinant laccase Lac by heterologous expression in E. coli, but its enzyme

320 activity was still lower. The intracellular enzyme may greatly reduce its original enzyme activity

321 during the process of isolation and purification due to physical damage, inducer, and improper

322 operation. Through directed evolution, two mutant laccases Lac ${ }^{\mathrm{ep} 69}$ and D500G with improved

323 enzyme activity were obtained. Among them, obtained by site-directed mutation has higher

324 enzyme activity, stability, and catalytic efficiency. This result is similar to that of some Bacillus

325 spp. (Wang, Lu \& Feng, 2017; Liu et al., 2011).

326 Whether it is random mutagenesis or site-directed mutation, changes in amino acid will affect

327 the spatial structure of the protein, which in turn affects the nature and function of the protein.

328 Studies have shown that factors such as the proportion of certain amino acids, protein

329 accumulation, hydrophobicity, increased helical fold content, internal hydrogen bonding and

330 density of salt bridges, and the distribution of charged residues on the surface are important factors

331 that affect protein thermal stability (Kumar \& Nussinov, 2001; Sterner \& Liebl, 2001).

332 Lac ${ }^{\text {ep69 }}$ mutated 6 amino acid positions, and cysteine at position 271 was mutated to basic

333 arginine, which may affect the optimal $\mathrm{pH}$ of the enzyme. The mutation of its non-polar isoleucine

334 at position 333 to polar threonine may affect the hydrophobicity of the protein. The change in

335 hydrophobicity, in turn, affects the stability of the protein.

336 Besides, the stability of protein structure is closely related to hydrogen bonds, because 1 mol of

337 hydrogen bonds can provide 0.6 calories of energy to maintain the stability of protein structure. 
338 The improvement of hydrogen bond introduced by the amino acid mutation at position 271 of

339 Lac $^{\text {ep69 }}$ is one of the important roles of enzyme protein stability (Mabrouk et al., 2011). The

340 cysteine at position 271 and the lysine at position 315 of Lac $^{\text {ep69 }}$ are both mutated to arginine.

341 Arginine can participate in a variety of non-covalent bond interactions, and its side chain can

342 provide more space for charge interactions. These factors further improve the stability of the

343 enzyme (KnoChel et al., 1996). D500G's acidic amino acid, aspartic acid, becomes glycine, and

344 the change in the optimal $\mathrm{pH}$ may be related to the change in the polarity of the amino acid. The

345 side chain of aspartic acid is "- $\mathrm{CH}_{2} \mathrm{COOH}$ " and the side chain of glycine is hydrogen atom "-H".

346 After the laccase mutation, the flexibility of the $\mathrm{N}-\mathrm{C}$ and $\mathrm{C}-\mathrm{C}$ framework changes, the binding

347 force between the enzyme and the substrate becomes stronger, and the enzyme activity improves.

348 Changes in properties caused by the 500 amino acid change have also been found in other bacterial

349 laccases (Koschorreck, Schmid \& Urlacher, 2009; Nasoohi et al., 2013).

350 The secondary and tertiary structure predictions show that Lac, Lac ${ }^{\mathrm{ep} 69}$, and D500G are similar

351 in structure, with little difference in physical and chemical properties. In general, the mutants only

352 form certain secondary bonds in the structure, and the distribution of the electron cloud is slightly

353 changed, but the sites that play a key role in the function of the enzyme are not changed. It is

354 noteworthy that D500G differs greatly from Lac in secondary structure, which may be one of the

355 reasons for its higher thermal stability and higher enzyme activity. Because the type and number

356 of intramolecular forces usually affect the thermal stability and catalytic activity of enzyme

357 molecules (Xie et al., 2014).

358 After analyzing the degradation of different kinds of dyes, it is found that wild-type and mutant 
359 laccases generally have lower degradation rates for methyl orange and higher degradation rates for

360 acid violet. From the analysis of enzyme specificity, laccase has different specificities for dye

361 molecules of different structures, and the degree of specific binding between the enzyme and the

362 substrate determines the degradation effect of the substrate. The anthraquinone structure of acid

363 violet belongs to the substrate dye of bacterial laccase laccase in this study, but has a low specificity

364 with azo methyl orange (Yaropolov et al., 1994; Galai, Youssoufi \& Marzouki, 2014). From the

365 perspective of mutants, D500G has the highest degradation rate for the three dyes among the three

366 enzymes. The reasons for this result come from three aspects. First, from the molecular level, the

367 mutation site of D500G structurally enhances its stability, which in turn affects its enzyme activity;

368 second, the structural change affects the affinity between the enzyme and the substrate, and $K \mathrm{~m}$

369 value is powerful evidence. According to the enzyme kinetic theory, the $K \mathrm{~m}$ value is negatively

370 correlated with the substrate affinity, and among the three, the $K \mathrm{~m}$ value of D500G is the smallest,

371 which is $10.50 \pm 0.32 \mathrm{mM}$.

372 From the temperature analysis, the optimal temperature of the mutant is significantly improved,

373 and high-temperature tolerance is also significantly increased. D500G still preserves more than

$37485 \%$ of the enzyme activity after being stored at a high temperature of $50-80^{\circ} \mathrm{C}$ for one hour, which

375 provides strong evidence for the improvement of the stability of the mutant. From the perspective

376 of $\mathrm{pH}$ analysis, the optimum $\mathrm{pH}$ of $\mathrm{D} 500 \mathrm{G}$ becomes larger, and at the same time, it still retains

377 more than $80 \%$ of the enzyme activity after being stored at 4.0-5.5 for one hour. The improvement

378 of temperature and $\mathrm{pH}$ tolerance increased the tolerance of $\mathrm{D} 500 \mathrm{G}$ in dyes, and at the same time

379 reducing the impact of the environment on enzyme activity, thereby increasing the mutant's 
380 degradation rate of dyes. The results of Fig. 5A-C also proved that the mutant has a higher

381 degradation rate in the first hour of the dye degradation process, and tends to end after 1 hour. It

382 is speculated that the enzyme activity of the laccase in 1 hour is due to various reasons. The

383 reduction ultimately leads to a decrease in its degradation rate.

384 CONCLUSION

385 In this study, we successfully screened a mutant laccase D500G with significantly improved

386 decolorization of dyes by site-directed mutagenesis. Compared with wild-type laccase, D500G has

387 significantly improved temperature and $\mathrm{pH}$ stability, which further enhances the tolerance of

388 laccase in the dye wastewater environment and is more suitable for practical industrial production.

389 ADDITIONAL INFORMATION AND DECLARATIONS

390 Conflicts of Interest

391 The authors declare no conflicts of interest.

\section{Author Contributions}

393 - Tongliang Bu conceived and designed the experiments, analyzed the data, drafted the work, or

394 revised it critically for important content, approved the final draft.

395 - Rui Yang conceived and designed the experiments, performed the experiments, prepared figures,

396 and tables.

397 - Yanjun Zhang and Yuntao Cai performed the experiments, prepared the figures and tables.

398 - Zizhong Tang, Chenglei Li, and Qi Wu analyzed the data, drafted the work, or revised it critically

399 for important content. 
400 - Hui Chen analyzed the data, drafted the work, or revised it critically for important content.

\section{REFERENCES}

402 Ali I, Peng C, Naz I, Lin D, Saroj DP, Ali M. 2019. Development and application of novel bio403 magnetic membrane capsules for the removal of the cationic dye malachite green in 404 wastewater treatment. RSC Advances. DOI: 10.1039/C8RA09275C.

405

406

407

408

409

410

411

412

413

414

415

416

417

418

Berman HM. 2008. The Protein Data Bank: a historical perspective. Acta Crystallographica Section A: Foundations of Crystallography 64:88-95. DOI: 10.1107/S0108767307035623.

Bhatia D, Sharma NR, Singh J, Kanwar RS. 2017. Biological methods for textile dye removal from wastewater: A review. Critical Reviews in Environmental Science \& Technology. DOI: 10.1080/10643389.2017.1393263.

Bornscheuer UT, Pohl M. 2001. Improved biocatalysts by directed evolution and rational protein design. Current Opinion in Chemical Biology 5:137-143. DOI: 10.1016/S1367$5931(00) 00182-4$

Bradford MM. 1976. A rapid and sensitive method for the quantitation of microgram quantities of protein utilizing the principle of protein-dye binding. Analytical Biochemistry 72:248-254. DOI: 10.1016/0003-2697(76)90527-3.

Chakroun H, Mechichi T, Martinez MJ, Dhouib A, Sayadi S. 2010. Purification and characterization of a novel laccase from the ascomycete Trichoderma atroviride: Application on bioremediation of phenolic compounds. Process Biochemistry 45:507-513. DOI: 

of Bacillus pumilus CotA-laccase by site-directed mutagenesis. Applied Microbiology and Biotechnology 101:1935-1944. DOI: 10.1007/s00253-016-7962-1.

Chen B, Xu W, Pan X, Lu L. 2015. A novel non-blue laccase from Bacillus amyloliquefaciens: Secretory expression and characterization. International Journal of Biological characterization of extracellular laccase from the ascomycete Paraconiothyrium variabile. Macromolecules 76:39-44. DOI: 10.1016/j.ijbiomac.2015.02.019.

Francis CA, Tebo BM. 2001. cumA multicopper oxidase genes from diverse Mn(II)-oxidizing and non-Mn(II)-oxidizing Pseudomonas strains. Applied \& Environmental Microbiology 67:4272-4278. DOI: 10.1128/aem.67.9.4272-4278.2001. of copper centers in phenoxazinone synthase: A new addition to the blue copper oxidase family. Biochemistry 32:4826-30. DOI: 10.1021/bi00069a018. SmLac/role of redox mediators in azo dye decolorization. Journal of Chemical Technology \& Biotechnology 89:1741-1750. DOI: 10.1002/jctb.4254. 
438 Givaudan A, Effosse A, Faure D, Potier P, Bouillant ML, Bally R. 1993. Polyphenol oxidase in 439 Azospirillum lipoferum isolated from rice rhizosphere: Evidence for laccase activity in non$440 \quad$ motile strains of Azospirillum lipoferum. Fems Microbiology Letters 108:205-210. DOI: 10.1111/j.1574-6968.1993.tb06100.x.

442 Gowri R, Vijayarghavan R, Meenambigai P. 2014. Microbial degradation of reactive dyes-A $443 \quad$ Review. 3:421-436.

444 Guan Z-B, Song C-M, Zhang N, Zhou W, Xu C-W, Zhou L-X, Zhao H, Cai Y-J, Liao X-R. 2014. 445 Overexpression, characterization, and dye-decolorizing ability of a thermostable, $\mathrm{pH}$-stable, 446 and organic solvent-tolerant laccase from Bacillus pumilus W3. Journal of Molecular Catalysis B: Enzymatic 101:1-6. DOI: 10.1016/j.molcatb.2013.11.009.

Hadibarata T, Yusoff ARM, Aris A, Salmiati, Hidayat T, Kristanti RA. 2012. Decolorization of Azo, Triphenylmethane and Anthraquinone Dyes by Laccase of a Newly Isolated Armillaria sp. F022. Water Air \& Soil Pollution 223:1045-1054. DOI: 10.1007/s11270-011-0922-6.

Hakulinen N, Rouvinen J. 2015. Three-dimensional structures of laccases. Cellular and Molecular Life Sciences 72:857-868. DOI: 10.1007/s00018-014-1827-5.

Halaburgi VM, Sharma S, Sinha M, Singh TP, Karegoudar TB. 2011. Purification and characterization of a thermostable laccase from the ascomycetes Cladosporium cladosporioides and its applications. Process Biochemistry 46:1146-1152. DOI: 10.1016/j.procbio.2011.02.002. 
457 KnoChel TR, Hennig M, Merz A, Darimont B, Kirschner K, Jansonius JN. 1996. The Crystal 458 Structure of Indole-3-glycerol Phosphate Synthase from the Hyperthermophilic 459 ArchaeonSulfolobus solfataricusin Three Different Crystal Forms: Effects of Ionic Strength. $460 \quad$ Journal of Molecular Biology 262:0-515. DOI: 10.1006/jmbi.1996.0531.

461 Koschorreck K, Richter SM, Ene AB, Roduner E, Schmid RD, Urlacher VB. 2008. Cloning and 462 characterization of a new laccase from Bacillus licheniformiscatalyzing dimerization of 463 phenolic acids. Applied Microbiology \& Biotechnology 79:217-224. DOI: 10.1007/s00253464 008-1417-2.

465 Koschorreck K, Schmid RD, Urlacher VB. 2009. Improving the functional expression of a Bacillus 466 licheniformis laccase by random and site-directed mutagenesis. BMC Biotechnology 9:12. 467 DOI: $10.1186 / 1472-6750-9-12$.

Kumar S, Nussinov R. 2001. How do thermophilic proteins deal with heat? Cell Mol Life Sci. Cellular \& Molecular Life Sciences Cmls 58:1216-1233. DOI: 10.1007/PL00000935.

Laemmli BUK. 1970. Cleavage of structural proteins during assembly of head of bacteriophageT4. Nature 227:680-685. DOI: 10.1038/227680a0. DOI: $10.1016 /$ j.jbiotec.2018.08.011.

475 Legrand, G, Martin, G. La laccase acide des champignons supérieurs. Relation entre la présence 
476

477

478

479

480

481

482

483

484

485

486

487

488

489

490

491

492

493

494

de cet enzyme et les conditions de développement chez Agaricus campestris. Qualitas Plantarum Et Materiae Vegetabiles 3-4, 521-528 (1958).

Liu Y, Ye M, Lu Y, Zhang X, Li G. 2011. Improving the decolorization for textile dyes of a metagenome-derived alkaline laccase by directed evolution. Applied Microbiology and Biotechnology 91:667-675. DOI: 10.1007/s00253-011-3292-5.

Lu L, Zhao M, Wang T, Zhao L, Du M, Li T, Li D. 2012. Characterization and dye decolorization ability of an alkaline resistant and organic solvents tolerant laccase from Bacillus licheniformis LS04. Bioresource Technology 115:35-40. DOI: 10.1016/j.biortech.2011.07.111.

Mabrouk SB, Aghajari N, Ali MB, Messaoud EB, Juy M, Haser R, Bejar S. 2011. Enhancement of the thermostability of the maltogenic amylase MAUS149 by Gly312Ala and Lys436Arg substitutions. Bioresour Technol 102:1740-1746. DOI: 10.1016/j.biortech.2010.08.082.

Martins LO, Durão P, Brissos V, Lindley PF. 2015. Laccases of prokaryotic origin: enzymes at the interface of protein science and protein technology. Cellular \& Molecular Life Sciences 72:911-922. DOI: 10.1007/s00018-014-1822-x.

Mendes S, Farinha A, Ramos CG, Leitão JH, Viegas CA, Martins LO. 2011. Synergistic action of azoreductase and laccase leads to maximal decolourization and detoxification of model dyecontaining wastewaters. Bioresource Technology 102:9852-9859. DOI: 10.1016/j.biortech.2011.07.108. 
495 Michniewicz A, Ledakowicz S, Ullrich R, Hofrichter M. 2008. Kinetics of the enzymatic 496 decolorization of textile dyes by laccase from Cerrena unicolor. Dyes and Pigments 77:295497 302. DOI: 10.1016/j.dyepig.2007.05.015.

498

500

501

502

503

504

505

506

507

508

509

510

511

512

513

Mishra S, Maiti A. 2018. The efficacy of bacterial species to decolourise reactive azo, anthroquinone and triphenylmethane dyes from wastewater: a review. Environmental Science and Pollution Research 25:8286-8314. DOI: 10.1007/s11356-018-1273-2.

Morozova OV, Shumakovich GP, Gorbacheva MA, Shleev SV, Yaropolov AI. 2007. "Blue” laccases. Biochemistry (Moscow) 72:1136-1150. DOI: 10.1134/S0006297907100112.

Mollania N, Khajeh K, Ranjbar B, Hosseinkhani S. 2011. Enhancement of a bacterial laccase thermostability through directed mutagenesis of a surface loop. Enzyme and Microbial Technology 49:446-452. DOI: 10.1016/j.enzmictec.2011.08.001.

Nasoohi N, Khajeh K, Mohammadian M, Ranjbar B. 2013. Enhancement of catalysis and functional expression of a bacterial laccase by single amino acid replacement. International Journal of Biological Macromolecules 60:56-61. DOI: 10.1016/j.ijbiomac.2013.05.011.

Pereira L, Coelho A, Viegas C, Ganachaud C, Iacazio G, Tron T, Robalo M, Martins L. 2009. On the Mechanism of Biotransformation of the Anthraquinonic Dye Acid Blue 62 by Laccases. Advanced Synthesis \& Catalysis. DOI: 10.1002/adsc.200900271.

Revanth BP, Niranjan M, Sarma Vv. 2020. Purification and characterization of Laccase from Nemania bipapillata (PUFNI 18745) and its application in degradation of Azo dyes. In: MSI 
515 Sakurai T, Kataoka K. 2007. Structure and function of type I copper in multicopper oxidases.

516 Cellular and Molecular Life Sciences 64:2642. DOI: 10.1007/s00018-007-7183-y.

517 Sakurai T, Kataoka K. 2010. Basic and applied features of multicopper oxidases, CueO, bilirubin 518 oxidase, and laccase. Chemical Record 7:220-229. DOI: 10.1002/tcr.20125.

519 Sterner RH, Liebl W. 2001. Thermophilic Adaptation of Proteins. CRC Critical Reviews in Biochemistry 36:39-106. DOI: 10.1080/20014091074174.

521 Tian Y-S, Xu H, Peng R-H, Yao Q-H, Wang R-T. 2014. Heterologous expression and

522 characterization of laccase 2 from Coprinopsis cinerea capable of decolourizing different 523 recalcitrant dyes. Biotechnology \& Biotechnological Equipment 28:248-258. DOI: $524 \quad 10.1080 / 13102818.2014 .913402$.

525 Tkaczyk A, Mitrowska K, Posyniak A. 2020. Synthetic organic dyes as contaminants of the aquatic 526 environment and their implications for ecosystems: A review. Science of The Total 527 Environment 717:137222. DOI: 10.1016/j.scitotenv.2020.137222.Wang C, Cui D, Lu L, Zhang N, Yang H, Zhao M, Dai S. 2016. Cloning and characterization of CotA laccase from Bacillus subtilis WD23 decoloring dyes. Annals of Microbiology 66:461-467. DOI: $10.1007 / \mathrm{s} 13213-015-1128-8$.

Wang J, Lu L, Feng F. 2017. Improving the Indigo Carmine Decolorization Ability of a Bacillus amyloliquefaciens Laccase by Site-Directed Mutagenesis. Catalysts 7:275. DOI: 
534 Wu J, Kim K-S, Lee J-H, Lee Y-C. 2010. Cloning, expression in Escherichia coli, and enzymatic 535 properties of laccase from Aeromonas hydrophila WL-11. Journal of Environmental Sciences

536 22:635-640. DOI: 10.1016/S1001-0742(09)60156-X.

Xie Y, An J, Yang G, Wu G, Zhang Y, Li C, Feng Y. 2014. Enhanced Enzyme Kinetic Stability by Increasing Rigidity within the Active Site. Journal of Biological Chemistry 289:79948006. DOI: $10.1074 /$ jbc.m113.536045.

Yaropolov AI, Skorobogat'Ko OV, Vartanov SS, Varfolomeyev SD. 1994. Laccase: properties, catalytic mechanism, and applicability. Applied biochemistry and biotechnology (USA).

Zeng J, Lin X, Zhang J, Li X, Wong M. 2011. Oxidation of polycyclic aromatic hydrocarbons by the bacterial laccase CueO from E. coli. Applied Microbiology \& Biotechnology 89:18411849. DOI: $10.1007 / \mathrm{s} 00253-010-3009-1$.

Zhang C, Diao H, Lu F, Bie X, Wang Y, Lu Z. 2012. Degradation of triphenylmethane dyes using a temperature and $\mathrm{pH}$ stable spore laccase from a novel strain of Bacillus vallismortis. Bioresource Technology 126. DOI: 10.1016/j.biortech.2012.09.055.

Zhang Y, Lv Z, Zhou J, Fang Y, Wu H, Xin F, Zhang W, Feng J, Xu N, He A, Liang D, Jiang M. 2019. Amperometric Biosensors Based on Recombinant Bacterial Laccase CotA for Hydroquinone Determination. Electroanalysis 32. DOI: 10.1002/elan.201900395.

Zheng F, An Q, Meng G, Wu X-J, Dai Y-C, Si J, Cui B-K. 2017. A novel laccase from white rot 
552 fungus Trametes orientalis: Purification, characterization, and application. International

553 Journal of Biological Macromolecules 102:758-770. DOI: 10.1016/j.ijbiomac.2017.04.089. 


\section{Figure 1}

SDS-PAGE analysis of pET- Lac

Images of strips stained with Coomassie Brilliant Blue R250. M: Marker; Lane 1: negative control; Lane 2-8: The products of induction $0 \mathrm{~h}, 2 \mathrm{~h}, 4 \mathrm{~h}, 6 \mathrm{~h}, 8 \mathrm{~h}, 10 \mathrm{~h}, 12 \mathrm{~h}$

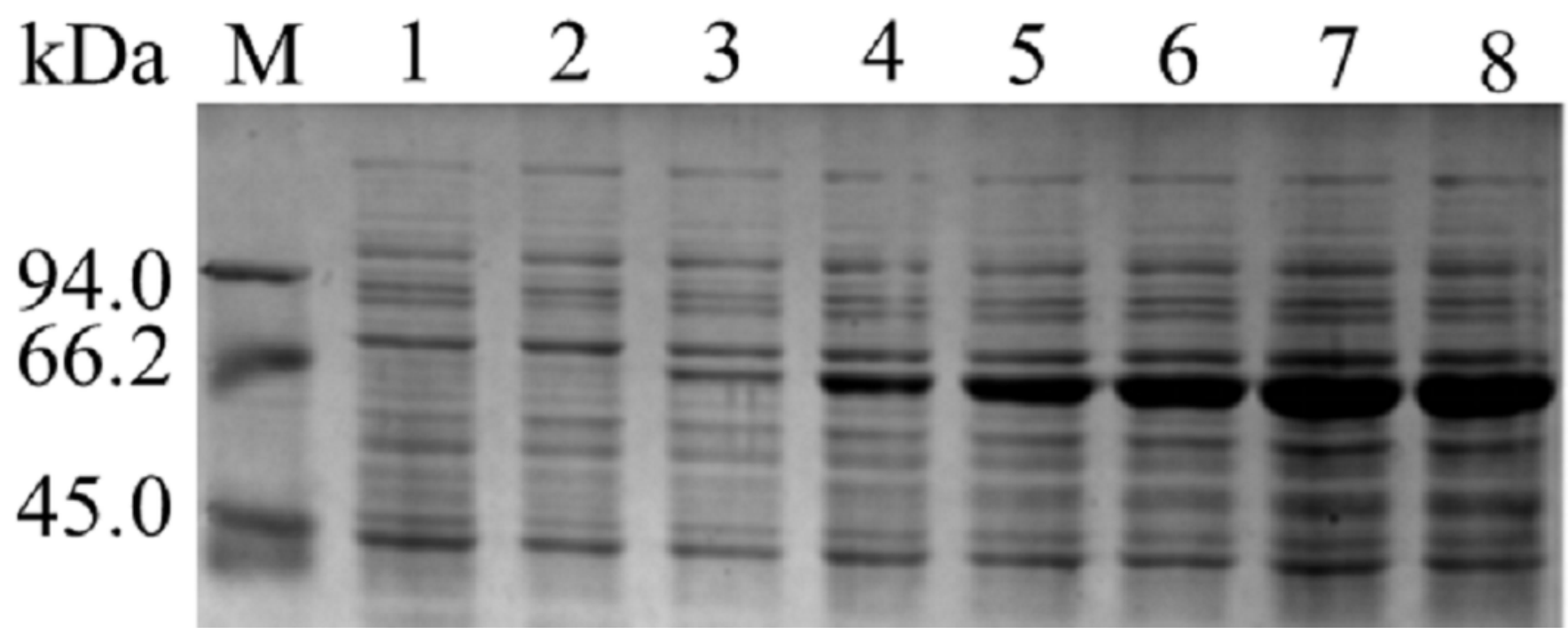


Figure 2

Detection of Lac purified SDS-PAGE

M: Marker; Lane 1: Purified product; Lane 2: intracellular supernatant; Lane 3: cell debris

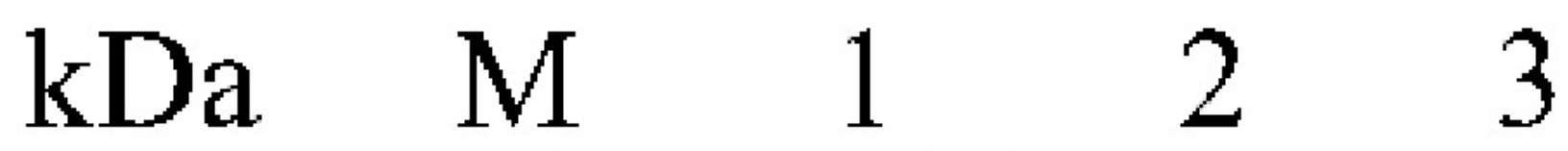

94.0
66.2

45.0 
Figure 3

Optimum $\mathrm{pH}$, temperature, and stability of engineering bacteria and mutants

A๑Optimum pH; B: pH stability; C: Optimum temperature; D: Temperature stability
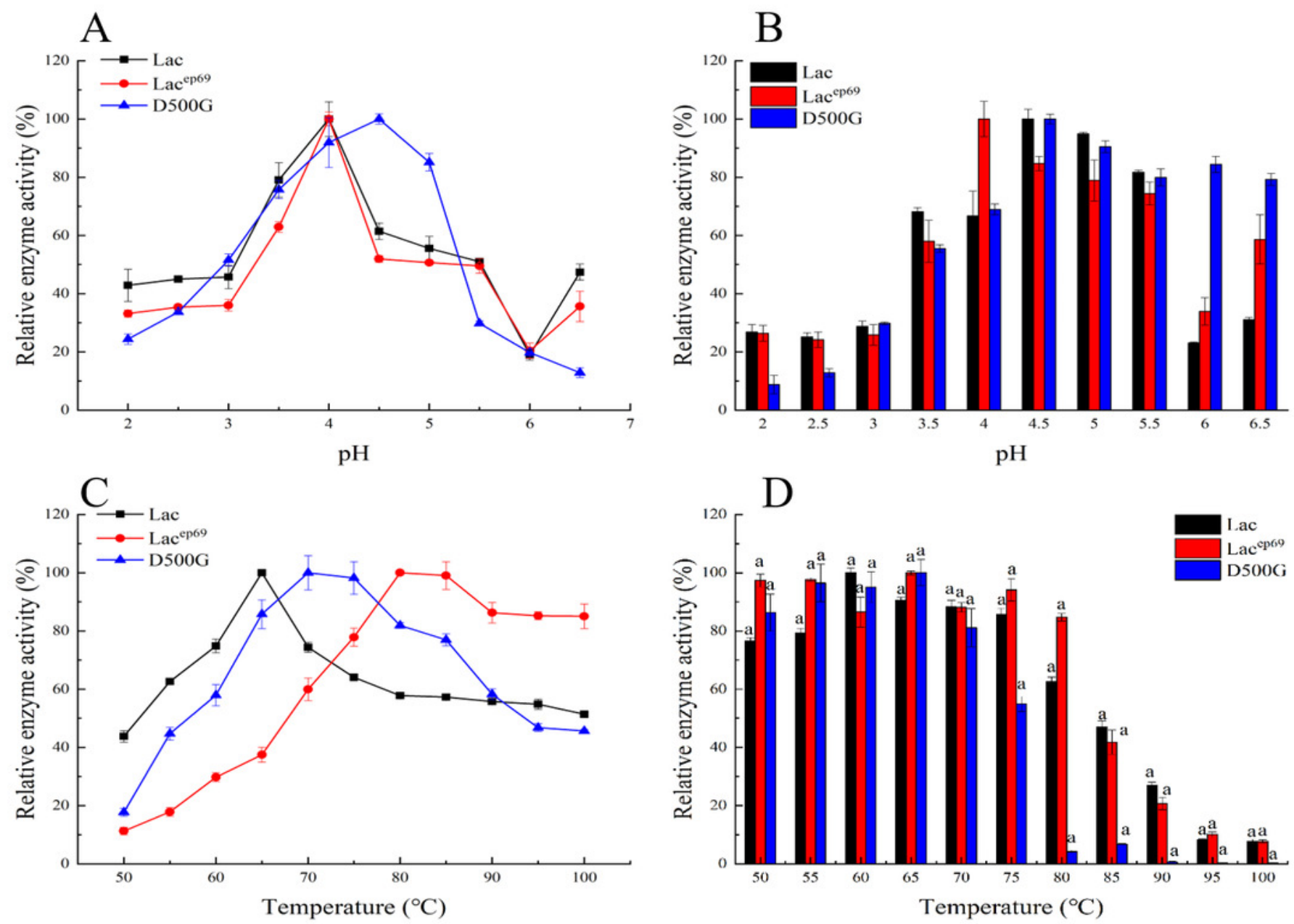
Figure 4

Effect of copper ion concentration on wild type and mutant laccase

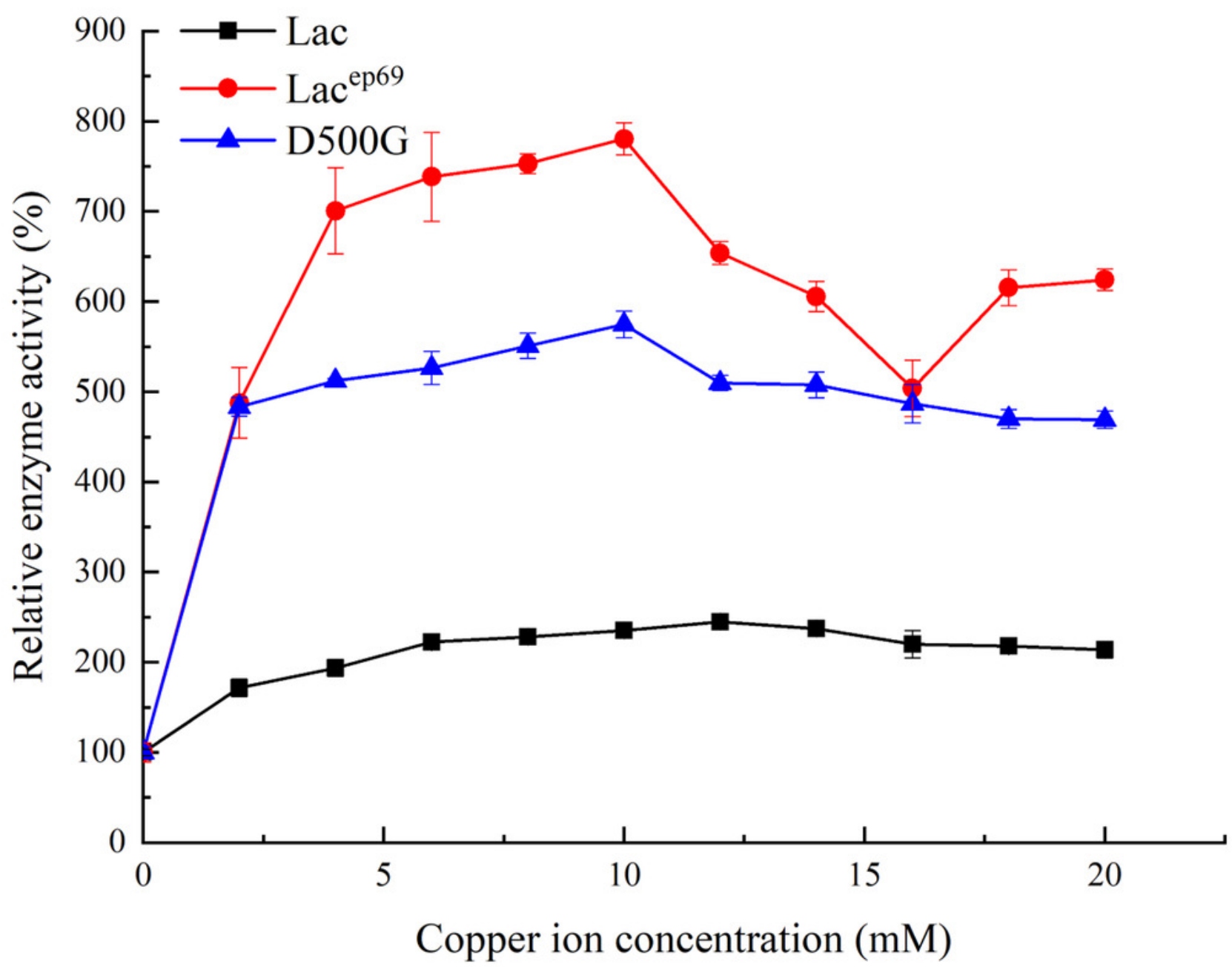


Figure 5

Degradation of dyes by different laccases

A, B, C: Decolorization of dyes by purified Lac, Lac ${ }^{\mathrm{ep} 69}, \mathrm{D} 500 \mathrm{G}$ at different time D:

Decolorization of dyes by purified Lac and its mutants Lac ${ }^{\mathrm{e} 69}$ and D500G in $1 \mathrm{~h}$
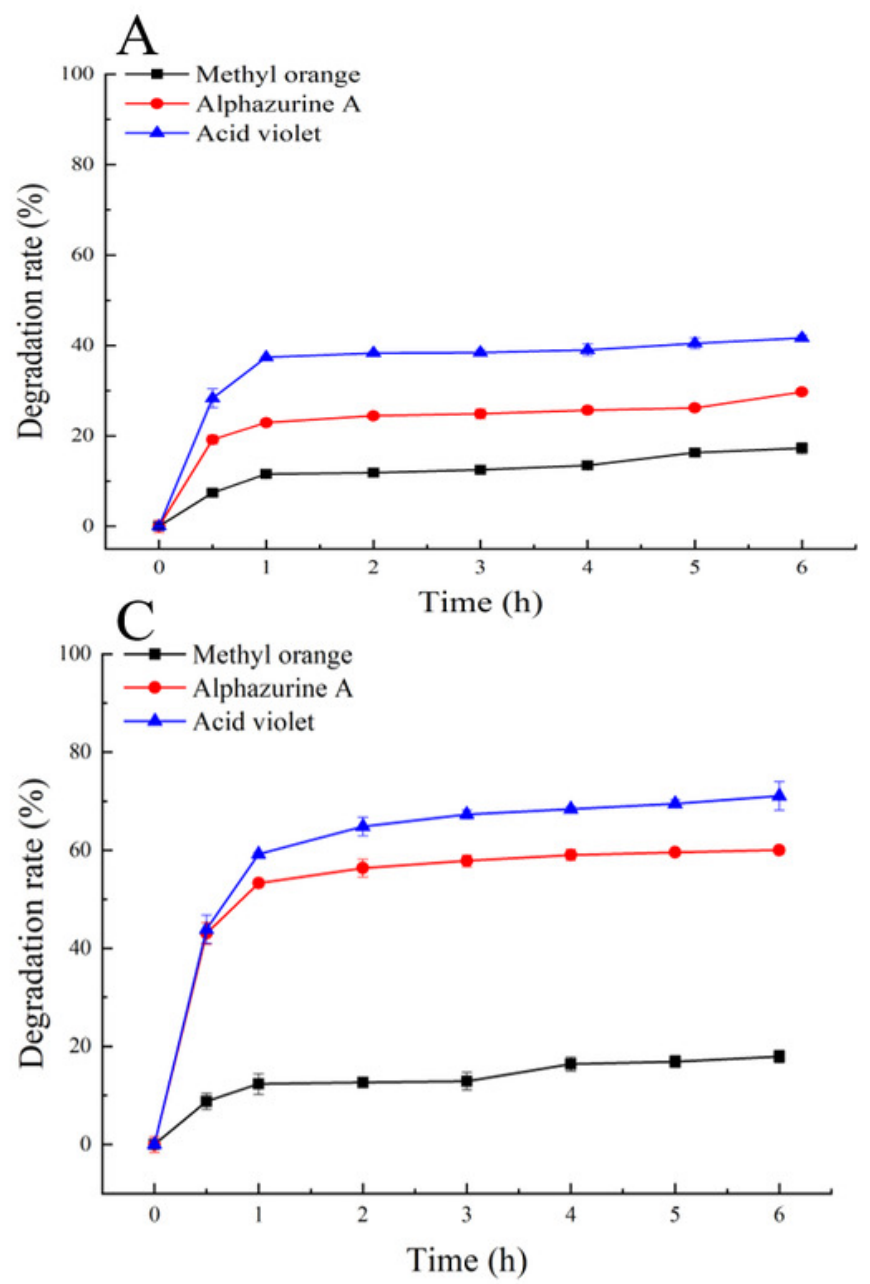

B
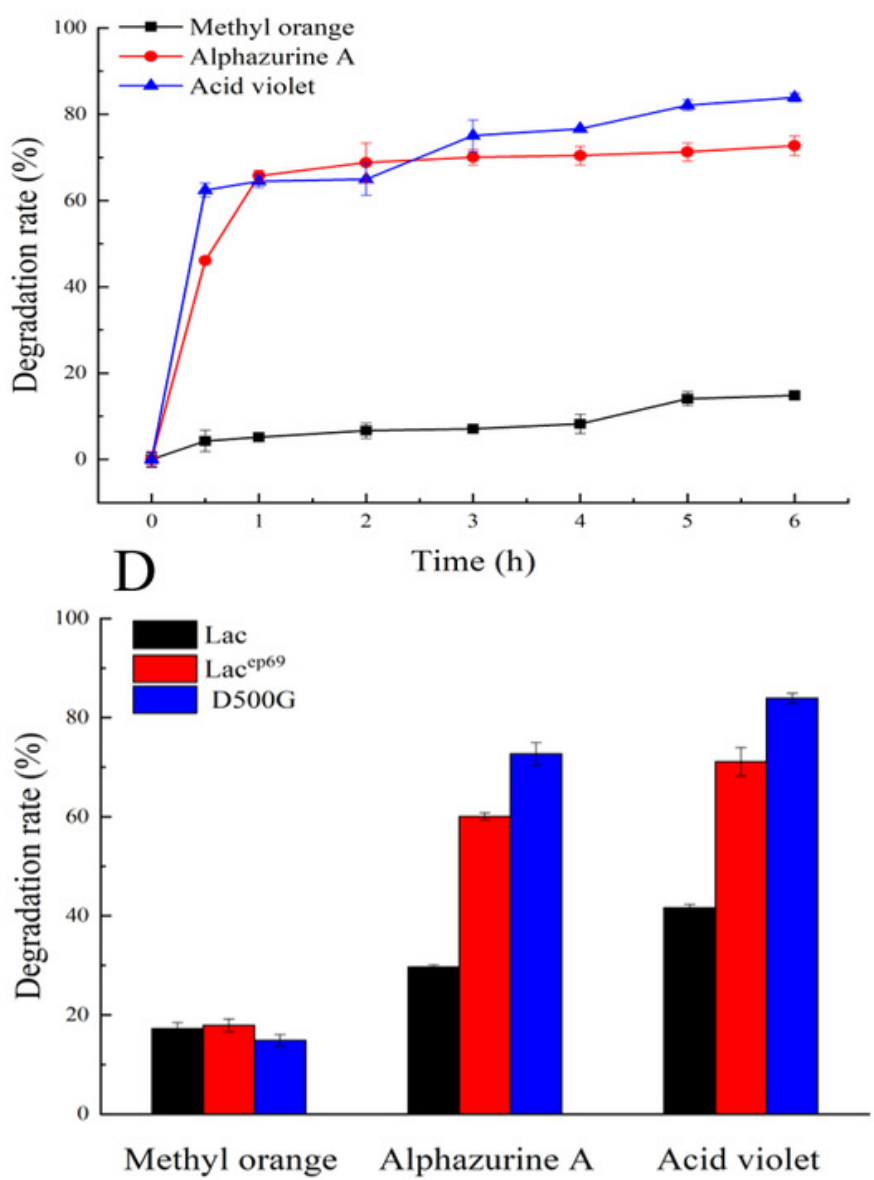
Figure 6

Hydrophobicity of Lac, Lac ${ }^{\mathrm{ep} 69}$, and D500G

A: Hydrophobicity of Lac; B: Hydrophobicity of Lac ${ }^{\mathrm{ep} 69}$; C: Hydrophobicity of D500G

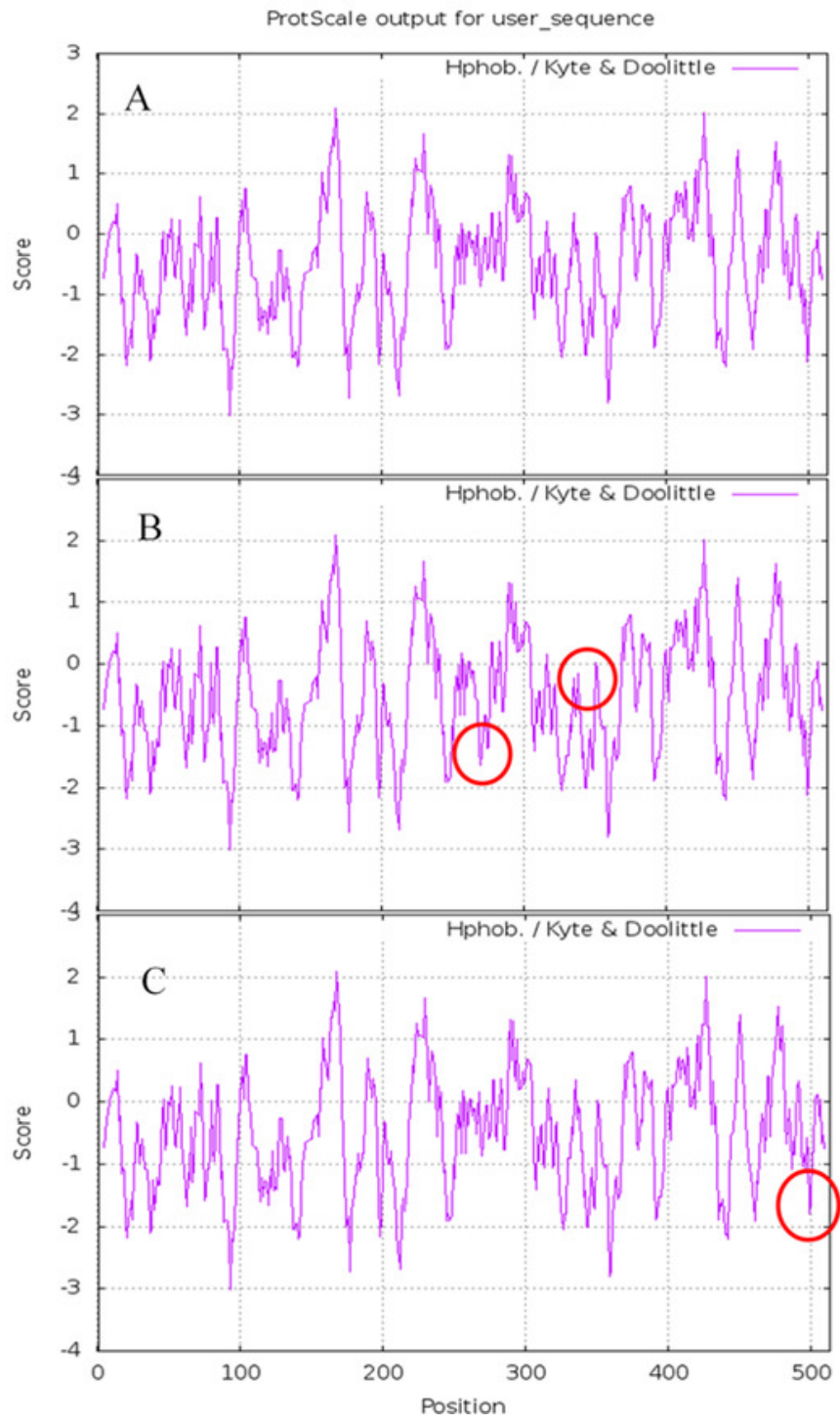


Figure 7

Prediction of the secondary structure of Lac, $\mathrm{Lac}^{\mathrm{e} 669}$, and D500G

Blue bars show $\alpha$-helix, green bars show $\beta$-turn, red bars show extended strand, purple bars

show random E. coli. A: Lac; B: Lac ${ }^{\mathrm{ep} 69}$; C: D500G

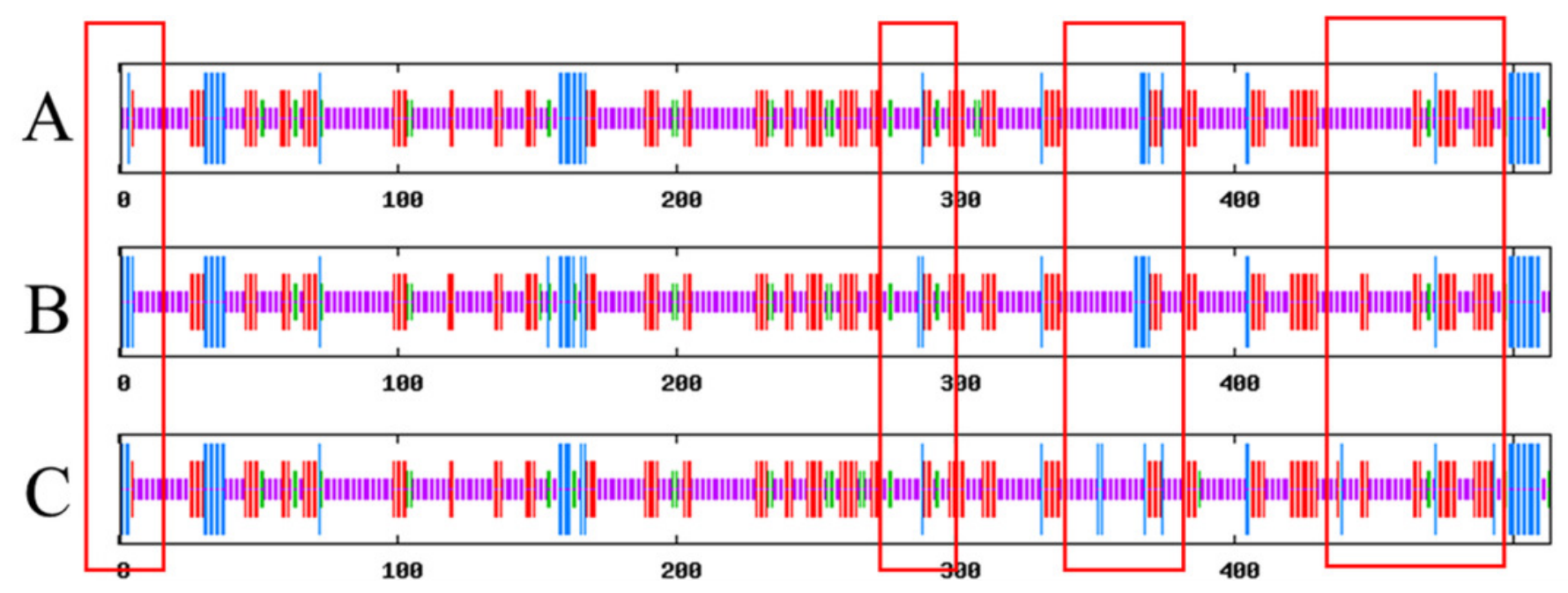




\section{Figure 8}

Prediction of the three-level structure prediction of Lac, Lac ${ }^{\mathrm{e} 699}$, and D500G

Red represents helix; blue represents strand, purple represents coil, and yellow represents a mutant amino acid. $A_{1} . A_{2}$ : Lac; B $\square$ Lac ${ }^{\mathrm{ep} 69} ; \mathrm{C}: \mathrm{D} 500 \mathrm{G}$.
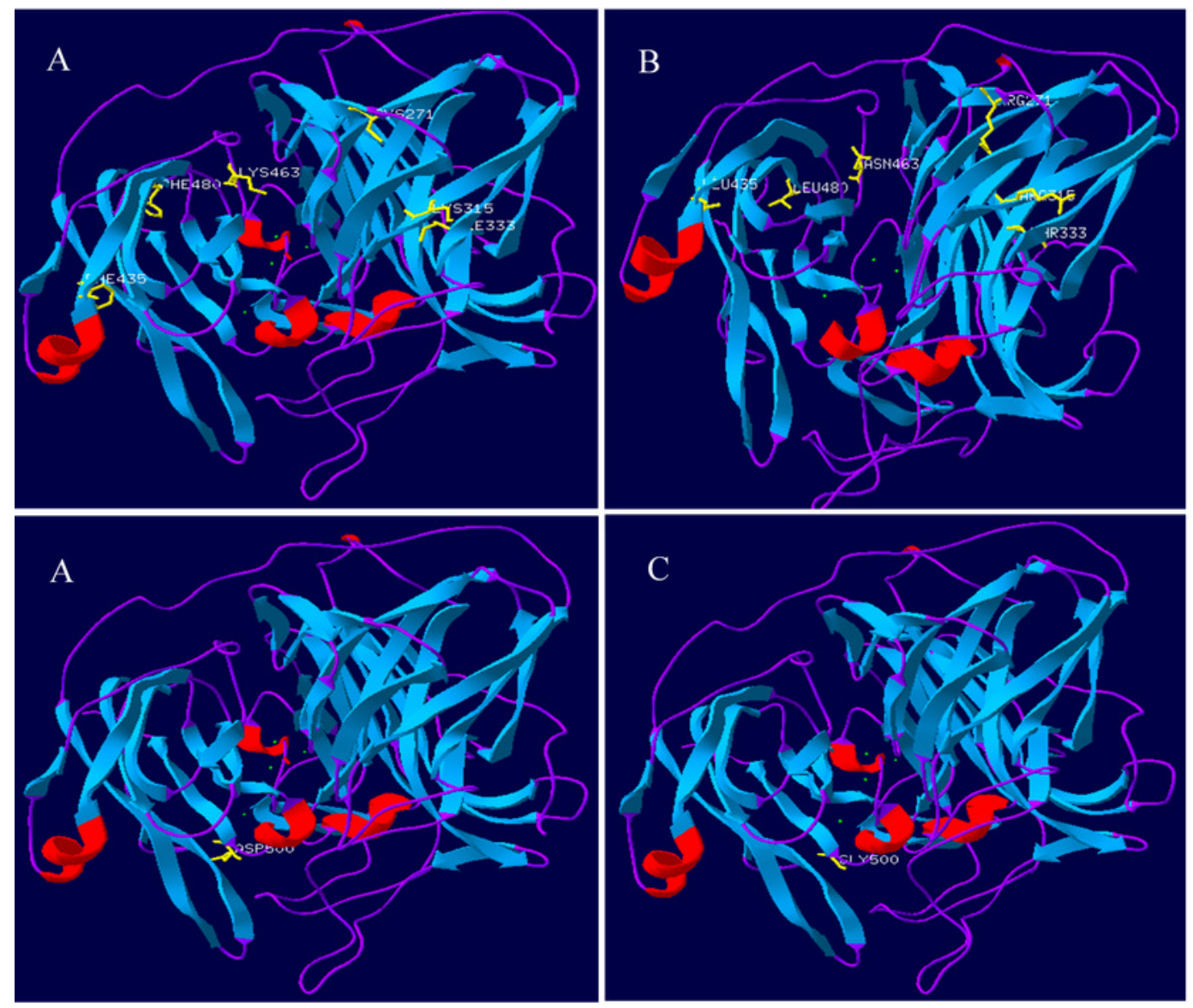


\section{Figure 9}

Hydrogen bond distribution of mutation sites of Lac, Lac ${ }^{\mathrm{ep} 69}$, and D500G

Yellow represents mutant amino acid; Green represents hydrogen bond; A, C, E, G, I, K, M:

Lac; B, D, F, H, J, L: Lac ${ }^{\mathrm{ep} 69} ; \mathrm{N}$ : D500G. Mutation sites are marked with red circles. Lac's Cys at position 271 and Val at position 287 form two hydrogen bonds; Lac ${ }^{\mathrm{ep} 69} \mathrm{~s} 271$ at Arg and Val at position 287 form two hydrogen bonds, and form a hydrogen bond with Leu at position 263. Lac's Ile at 315 and Tyr at 264 forms two hydrogen bonds, which may collide with atoms in Thr at 313; Lac ${ }^{\mathrm{e} 699} \mathrm{~s} 315 \mathrm{Arg}$ and Tyr at 264 forms two hydrogen bonds. Lac's Phe at 435 forms a hydrogen bond with lle at position 437 and Gly at position 471; Lac Lac ${ }^{\mathrm{ep} 69}$ s Leu at position 435 forms a hydrogen bond with lle at position 437, which may collide with an atom in Gly at position 437. Lac's aspartic acid at position 500 and leucine at position 385, tryptophan at position 392 and methionine at position 502 each form a hydrogen bond; glycine at position 500 of D500G and the methionine at position 502 each forms a hydrogen bond, and the atoms in histidine at position 496 may collide. 

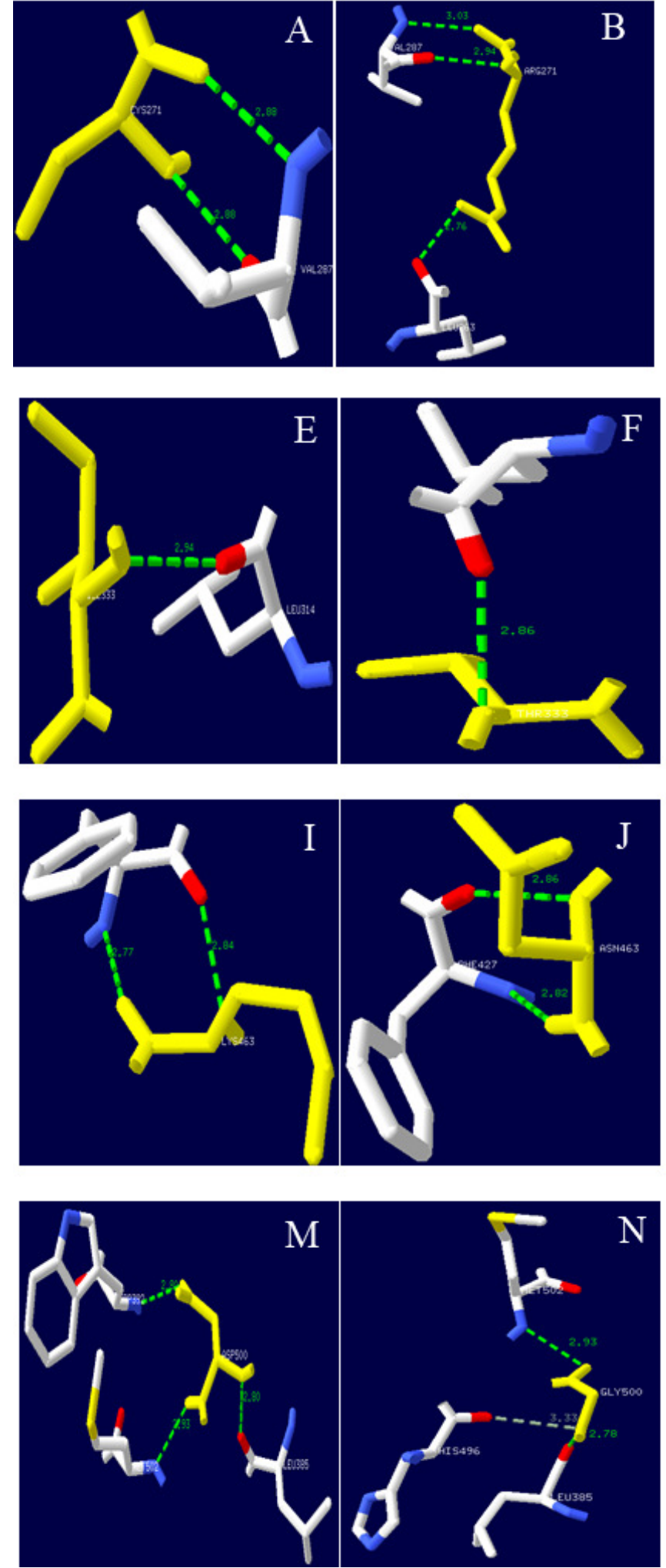
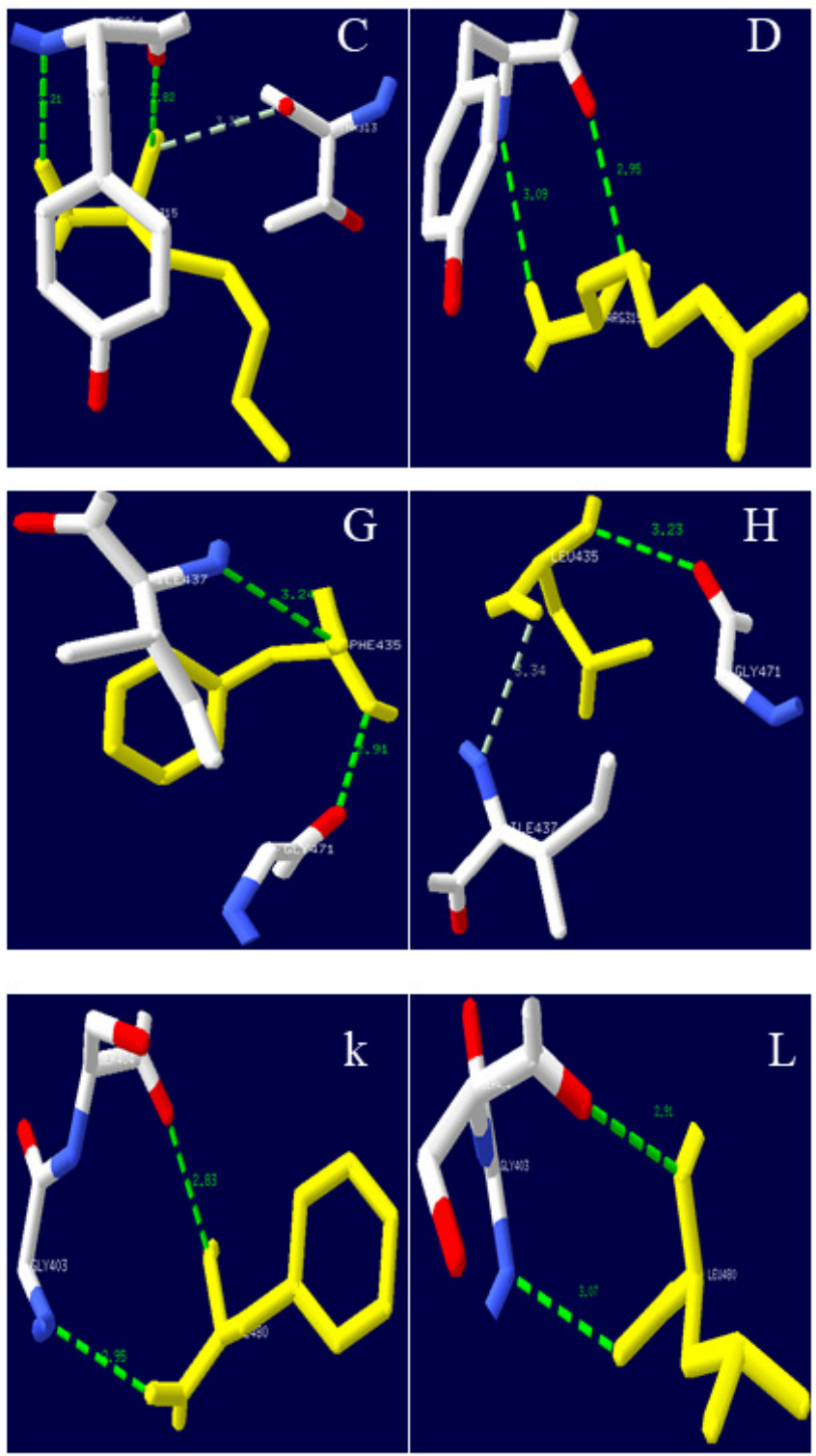
Table $\mathbf{1}$ (on next page)

Strains and plasmids 
1 Table 1 :

2 Strains and plasmids

\begin{tabular}{|c|c|c|c|}
\hline Strains/plasmid & & Genotype/description & Source \\
\hline pET- Lac & & A recombinant plasmid containing with wild gene $L a c$ & Laboratory \\
\hline pET- Lacep69 & & A recombinant plasmid containing with mutant gene $\mathrm{Lac}^{\mathrm{ep} 69}$ & Laboratory \\
\hline pET- D500G & & A recombinant plasmid containing with mutant gene D500G & Laboratory \\
\hline E. coli $\mathrm{DH} 5 \alpha$ & & Competent cells of plasmid cloning host bacteria & Takara \\
\hline $\begin{array}{l}\text { E. coli } \\
(\mathrm{DE} 3)^{2}\end{array}$ & BL21 & Competent cells of plasmid expression host bacteria & Takara \\
\hline pMD19-T & & Cloning vector & Takara \\
\hline pET-30b (+) & & Expression vector & Takara \\
\hline FDM & & Competent cells of plasmid cloning host bacteria & Tiangen \\
\hline
\end{tabular}

3 
Table 2 (on next page)

Primers for PCR 
1 Table 2:

2 Primers for PCR

\begin{tabular}{ll}
\hline Primer & Sequence $\left(5^{\prime} \rightarrow 3^{\prime}\right)$ \\
\hline Lac-M-F & GACAGCCCAGATCTGGGTACCATGAAACTTGAAAAATTCGTTGACC \\
Lac-M-R & TTGTCGACGGAGCTCGAATTCTTATTGATGACGAACATCTGTCACTT \\
Lac-M-1-R & CAAAGATTCTCGTATTGGAGGCGT \\
Lac-M-2-F & ATACTGAACGCCTCCAATACGA \\
Lac-D-F & CCTTGTCGACGAAGATTACGGTATGATGCGC \\
\hline Lac-D-R & CCGTAATCTTCCAACTCAAGGATGTGGCAGT \\
\hline
\end{tabular}

3 
Table 3 (on next page)

Physicochemical properties of Lac, $\operatorname{Lac}^{\mathrm{ep} 69}$ and D500G 
1 Table 3:

2 Physicochemical properties of Lac, $\mathrm{Lac}^{\mathrm{e} 69}$ and D500G

\begin{tabular}{cccccc}
\hline Strain & $\begin{array}{c}\text { molecular } \\
\text { weight (Da) }\end{array}$ & $\begin{array}{c}\text { isoelectric } \\
\text { point }\end{array}$ & $\begin{array}{c}\text { positively charged } \\
\text { residues }\end{array}$ & $\begin{array}{c}\text { negatively } \\
\text { charged residues }\end{array}$ & $\begin{array}{c}\text { instability } \\
\text { coefficient }\end{array}$ \\
\hline Lac & 59074.20 & 6.25 & 60 (Arg+Lys) & $70($ Asp+Glu) & 40.03 \\
Lacep69 & 59061.11 & 6.25 & 60 (Arg+Lys) & $70($ Asp+Glu) & 39.57 \\
D500G & 59016.17 & 6.31 & 60 (Arg+Lys) & $70($ Asp+Glu) & 39.40 \\
\hline
\end{tabular}

3 